\title{
Cradle to grave GHG emissions analysis of shale gas hydraulic fracking in Western Australia
}

\author{
Sangita Bista*, Philip Jennings, and Martin Anda \\ School of Engineering and Information Technology, Murdoch University, Western Australia 6150, Australia
}

Received: 29 January 2017 / Received in final form: 4 July 2017 / Accepted: 27 July 2017

\begin{abstract}
Western Australia has globally significant onshore gas resources, with over 280 trillion cubic feet of economically recoverable gas located in five shale basins. The Western Australian Government and gas industry have promoted the development of these resources as a "clean energy source" that would "help to reduce global carbon emissions" and provide a "transition fuel" to a low carbon economy. This research examines those claims by reviewing existing literature and published data to estimate the life cycle greenhouse gas (GHG) pollution that would result from the development of Western Australia's onshore gas basins using hydraulic fracking. Estimates of carbon pollution from each stage in gas development, processing, transport and end-use are considered in order to establish total life-cycle emissions in tonnes of carbon-dioxide equivalent $\left(\mathrm{CO}_{2} \mathrm{e}\right)$. The emissions estimates draw from published research on emissions from shale gas development in other jurisdictions as well as industry or government reported emissions from current technology for gas processing and end-use as applicable. The current policy and regulatory environment for carbon pollution and likely resulting GHG mitigation measures has also been considered, as well as the potential for the gas to displace or substitute for other energy sources. In areas where there is uncertainty, conservative emissions estimates have been used. Modelling of GHG emissions has been undertaken for two comparison resource development and utilisation scenarios; Australian domestic and 100\% export i.e. no domestic use. Each scenario corresponds to a different proportionate allocation of emissions accounted for domestic emissions in Australia and emissions accounted for in other jurisdictions. Emissions estimates for the two scenarios are $245-502 \mathrm{MTCO}_{2} \mathrm{e} / \mathrm{year}$ respectively over a resource development timeframe of 20 years. This is roughly the same as Australia's total GHG emissions in 2014 which were $525 \mathrm{MTCO}_{2} \mathrm{e} /$ year. This research concludes that GHG emissions resulting from the development of Western Australia's five onshore gas basins would be equivalent to all other Australian emissions sources combined at 2014 levels each year for 20 years which is the general lifetime of a well.
\end{abstract}

\section{Introduction}

This study examines and analyses the life cycle of greenhouse gas (GHG) emissions that would occur by hydraulic fracking for the production of shale gas in Western Australia. Continued advances in horizontal drilling techniques, combined with a "hydraulic fracturing" process, are providing access to previously uneconomical natural gas resources. According to the Environmental Protection Agency (EPA) large reserves of this "unconventional" natural gas (unconventional gas) have been identified and are distributed globally [1]. It is predicted that there will be the greatest growth for shale gas, from $16 \%$ of total production in 2009 to an expected $45 \%$ in 2035 globally [2]. Considering such an increasing rate of extraction and the labelling of the unconventional source as a "transition fuel" between coal

\footnotetext{
* e-mail: s.bista@murdoch.edu.au
}

(and other high-emission fuels) and renewable sources of energy, it is vital to understand potential climate impact of shale gas fracking to reach a higher level of certainty with regard to the scale of its impacts. Also, the environmental impact of the extraction of unconventional gas sources is under scrutiny in Australia since this country is on the verge of exploiting its shale gas resources. The GHG emissions from the development of unconventional (shale) gas from hydraulic fracking are different from those of the conventional gas. In fracking, the methane escapes from the flow back and drill out following the fracturing, unlike the development of conventional gas [3]. Methane $\left(\mathrm{CH}_{4}\right)$ is a short-lived GHG gas. It has a dominant GHG effect, with a Global Warming Potential (GWP) 86 times that of $\mathrm{CO}_{2}$ over the 20 years' time period [3]. In addition methane has 25 times intensive GWP that of $\mathrm{CO}_{2}$ in 100 years [4]. Another major portion of the carbon dioxide $\left(\mathrm{CO}_{2}\right)$ emissions in the lifecycle analysis of fracking occurs during the end use of the gas such as for electricity generation [5]. 


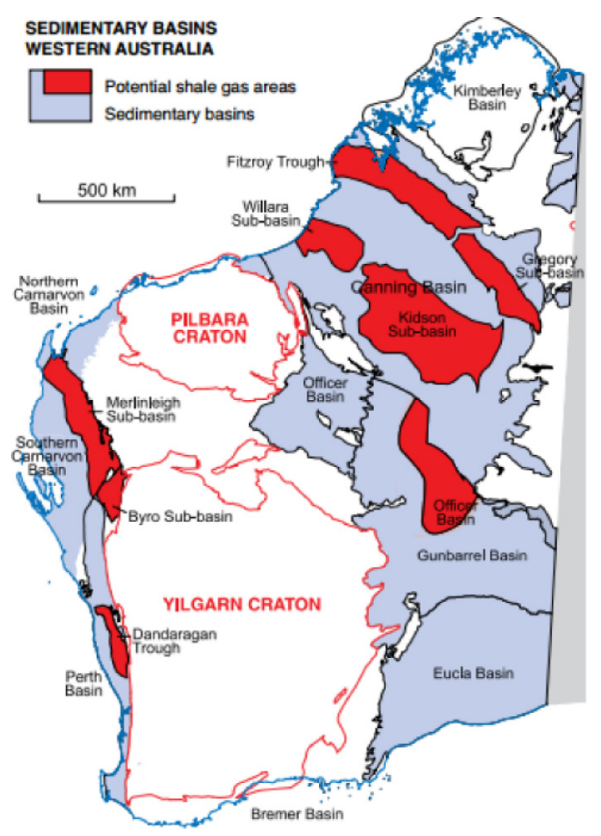

\begin{tabular}{|l|l|}
\hline \multicolumn{2}{|l|}{ Shale gas basins in WA } \\
\hline Basins & Resource Volume (TCF) \\
\hline North Perth Basin & 15 \\
\hline Canning Basin & 230 \\
\hline Carnarvon Basin & 15 \\
\hline Officer Basin & 10 \\
\hline South Perth Basin & 10 \\
\hline Total & 280 \\
\hline $\begin{array}{l}\text { Source: (Western Australia Government 2015) } \\
\text { 1 Trillion Cubic Feet }=28316 \text { 846 592 cubic metres } \\
\text { (Equivalent to a Quad or a quadrillion Btu's (EIA 2016) }\end{array}$ \\
\hline
\end{tabular}

Fig. 1. Map showing WA onshore gas basins.

In this context, full estimation of the impact of shale gas production and use requires an assessment with an integrated Life Cycle Assessment (LCA) approach. LCA is an environmental management methodology for researching the impact a product has on the environment [6]. This paper uses the LCA approach to estimate the GHG footprint of fracking and compares this with Australia's carbon budget. There are five shale gas basins known so far in WA (Fig. 1) with a total volume of about 280 trillion cubic feet (TCF) of natural gas $[7,8]$.

\section{Methodology}

This study reviews available literature and data sources related to fugitive emissions from the production of unconventional gas. Emission factors consistent with the Intergovernmental Panel on Climate Change (IPCC) good practice methodology [4] are used. Information and data used are taken from the most recent sources available predominantly from the USA literature, as there are limited sources of information from other countries. Secondary data is taken from reports and papers dating from 2010 to present. These sources were selected based on the quality of the information and to provide a balanced contribution from the scientific community, industry representatives and the environmental administration (EPA). Unconventional sources of natural gas are still a relatively new fuel source and consequently there remains a shortage of verified data on the factors that affect fugitive emission levels. Any assumptions that have been made in light of data shortages are clearly identified (Tab. 1).

Additionally, reference data from scientific journals, public submissions in Australia, Department of Mines and Petroleum (DMP) and other literature has been used. This study uses the recent technical background papers on GHG emissions from the USA experience in the shale gas industry. The WA shale gas basins have an average of 78 $80 \%$ of methane gas content $[9,10]$ making them comparable in terms of the fugitive emissions factors of the basins having similar gas content to the USA Haynesville and Barnette gas basins. There is no standard data available for fugitive emissions from accidents and emergencies and hence they are excluded. Some relevant data from [11] for Australia has been used to estimate GHG emissions from liquefied natural gas (LNG) processing, distribution and electricity generation. At the end use, export to China has been used as the estimate for international emissions. Asia is the closest market for Australia.

In order to address the uncertainty, possible emissions ranges have been estimated for each stage of shale gas development wherever applicable. Since LCA is an iterative process, the model developed for this study can be updated as more data becomes available. A similar approach has been used by a number of organisations such as the IISAS and Exxon Mobil. The emissions that are considered in this study come from the $\mathrm{CO}_{2}$, the $\mathrm{CH}_{4}$, from the venting or flaring fugitive gas, emissions from the transport and the treatment of the gas (Tab. 1). The emissions from the construction of the equipment, from the land use, from the chemicals injected during the extraction process or from exploration wells are not considered in this paper.

\section{Results}

\subsection{Emissions from well completion}

The fugitive emissions during well completion can vary across the shale gas basins, which is mainly due to lack of standard data [3]. The emissions during well completion are the combination of flow back plus the drill out. During fracking, a significant volume of water returns to the 
Table 1. Emission source inclusions/exclusions.

Inclusions

- Venting and flaring

- Well completion

- Emissions from processing

- LNG processing

Exclusions

- Use of grid

- Pipeline distribution in China

- Construction emissions for the drilling pad and bore whole
- Regasification (international)

- Transport (LNG)

- End use (electricity)

- Well leaks

\section{Remarks}

- Data NA for operations

- It is assumed that the energy used in the pipeline distribution is not material - Data NA
Table 2. Well completion emission $\left(\mathrm{MTCO}_{2} \mathrm{e}\right)$ for entire field.

\begin{tabular}{llll}
\hline $\begin{array}{l}\text { Fugitive } \mathrm{CH}_{4} \\
\left(\mathrm{~m}^{3}\right)\end{array}$ & $\begin{array}{l}\text { Fugitive } \mathrm{CH}_{4} \\
(\mathrm{t})\end{array}$ & $\begin{array}{l}\mathrm{CO}_{2} \mathrm{e} \\
(\mathrm{t})\end{array}$ & $\mathrm{MTCO}_{2} \mathrm{e}$ \\
\hline $1.51 \mathrm{E}+11$ & $1.02 \mathrm{E}+08$ & $2.56 \mathrm{E}+09$ & 2559.85 \\
\hline
\end{tabular}

surface known as the "flowback"[12]. The drill out is the stage where the plugs set to separate fracturing stages are drilled out in order to release the natural gas for further production [13]. The lowest emissions, recorded in the Uinta basin the USA, were $1.6 \%[3,13]$. Therefore, $1.6 \%$ has been used as the flowback factor in this model. Also, this paper takes the drill out emissions to be $0.33 \%$ based on the EPA [14]. Thus, the total well completion factor is $1.9 \%$ (flow back plus drill-out). An estimate of GHG emissions for extracting $280 \mathrm{TCF}$ of shale gas in terms of $\mathrm{CO}_{2}$ equivalents associated with well completion is $2560 \mathrm{MTCO}_{2}$ e (Tab. 2).

\subsection{Well leaks and underground containment failure}

Subsurface pathways, such as abandoned oil and gas wells and faults, can serve as leakage pathways for $\mathrm{CO}_{2}$, methane, brine, and other fluids. These pathways allow fluids from deep subsurface formations to migrate into shallow groundwater aquifers or to the atmosphere [12]. The abandoned oil and gas wells and conductive faults in geologic formations serve as leakage pathways for fluids which would otherwise remain trapped beneath low-permeability layers[15]. Those leaky faults and abandoned wells must be considered in many engineering activities such as geological sequestration of $\mathrm{CO}_{2}$ [16]. Cornell University has reported natural gas wells leaking methane could be at about the same rate reported in the U.S. Environmental Protection Agency methane emission inventories (roughly around 3-6\%) as the lower limit [17]. During the fracking process, in each stage, a certain amount of methane is lost as fugitives. That is, the actual volume needs to be figured out to estimate the fugitives lost from well leaks.
Therefore, this paper has introduced an "actual volume" which is calculated as;

$$
V_{\text {actual }}=V_{\text {last }}-V_{\text {lost }},
$$

where $V_{\text {actual }}$ is the actual volume used in the next calculations; $V_{\text {last }}$ is the last volume used; and $V_{\text {lost }}$ is the lost volume gas from the previous step.

The potential well leaks and underground containment failure emissions are estimated to be a minimum of $3965 \mathrm{MTCO}_{2} \mathrm{e}$ to maximum of $7930 \mathrm{MTCO}_{2} \mathrm{e}$ for extracting 280 TCF of shale gas (Tab. 3).

\subsection{Emissions from venting}

Venting is the controlled release of gases into the atmosphere in the course of oil and gas production operations [18]. Under current legislation, venting is permitted in the WA $[19,20]$. So, it is important to estimate this. A separate model is established for accounting the $\mathrm{CH}_{4}$ fugitives and the direct $\mathrm{CO}_{2} \mathrm{e}$ emissions during venting, using standard factors developed by Glancy [4] using the IPCC guidelines. The $\mathrm{CH}_{4}$ fugitive emissions are converted into $\mathrm{CO}_{2}$ e for a 100-year GWP. The total venting emissions are found to be $1061 \mathrm{MTCO}_{2} \mathrm{e}$ (Tab. 4) which is about the double that of Australian national emissions for the year 2014 which was $525 \mathrm{MTCO}_{2} \mathrm{e}[8]$. It is the total venting emission for extracting all of the resource $(280 \mathrm{TCF})$ from WA shale basins.

\subsection{Flaring}

Flaring is the controlled burning of natural gas in the course of routine gas production operations [18]. Efficient combustion in the flame depends on achieving good mixing between the fuel gas and air, and on the absence of liquids. While calculating the emissions, one has to use the facts for both $\mathrm{CO}_{2}$ and $\mathrm{CH}_{4}$, as other impurities (along with methane) are also burnt during the process [21]. As flaring is also not prohibited in WA, it is estimated to be $241 \mathrm{MTCO}_{2} \mathrm{e}$ (Tab. 5). 
Table 3. Emissions (tonnes) from well leaks for the entire field.

\begin{tabular}{llllll}
\hline Fugitive max & Fugitive min & $\mathrm{CO}_{2} \mathrm{e} \max$ & $\mathrm{CO}_{2} \mathrm{e} \min$ & $\mathrm{MTCO}_{2} \mathrm{e} \min$ & $\mathrm{MTCO}_{2} \mathrm{e} \max$ \\
\hline $3.17 \mathrm{E}+08$ & $1.59 \mathrm{E}+08$ & $7.93 \mathrm{E}+09$ & $3.97 \mathrm{E}+09$ & 3965 & 7930 \\
\hline
\end{tabular}

Table 4. Emission from venting during the production of shale gas from entire gas field.

\begin{tabular}{lllll}
\hline Actual volume $\left(\mathrm{m}^{3}\right)$ & $\mathrm{CH}_{4}\left(\mathrm{~m}^{3}\right)$ & $\mathrm{CO}_{2}\left(\mathrm{~m}^{3}\right)$ & $\mathrm{CO}_{2} \mathrm{e}(\mathrm{t})$ & $\mathrm{MTCO}_{2} \mathrm{e}$ \\
\hline $7.31 \mathrm{E}+12$ & $4.24 \mathrm{E}+07$ & $1.83 \mathrm{E}+06$ & $1.06 \mathrm{E}+09$ & 1061 \\
\hline
\end{tabular}

Table 5. Emission from flaring from extraction of all the gas resources from WA.

\begin{tabular}{llllll}
\hline Shale gas WA & Volume $\left(\mathrm{m}^{3}\right)$ & $\mathrm{CH}_{4}\left(\mathrm{~m}^{3}\right)$ & $\mathrm{CO}_{2}\left(\mathrm{~m}^{3}\right)$ & $\mathrm{tCO}_{2} \mathrm{e}$ & $\mathrm{MTCO}_{2} \mathrm{e}$ \\
\hline 280 & $7.31 \mathrm{E}+12$ & $1.46 \mathrm{E}+06$ & $2.05 \mathrm{E}+08$ & $2.41 \mathrm{E}+08$ & 241 \\
\hline
\end{tabular}

Table 6. Estimated processing loss emission.

\begin{tabular}{llllll}
\hline Shale gas WA & Volume $\left(\mathrm{m}^{3}\right)$ & $\mathrm{CH}_{4}\left(\mathrm{~m}^{3}\right)$ & $\mathrm{CH}_{4}(\mathrm{t})$ & $\mathrm{CO}_{2} \mathrm{e}(\mathrm{t})$ & $\mathrm{MTCO}_{2} \mathrm{e}$ \\
\hline 280 & $7.31 \mathrm{E}+12$ & $1.39 \mathrm{E}+10$ & $9.44 \mathrm{E}+06$ & $2.36 \mathrm{E}+08$ & 236 \\
\hline
\end{tabular}

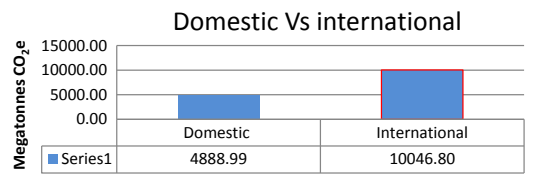

Fig. 2. Domestic and international emission for all shale gas fields - WA.

\subsection{Processing loss}

Not all the gas produced is "pipeline ready". The produced gas requires further processing. The gas impurities would contain sufficient amounts of impurities such as heavy hydrocarbons and sulphur gases that need to be removed before the gas is piped. The range used for pipeline ready is $0.19 \%$ as suggested by Howarth et al. [3,19]. The estimated emissions from processing loss are $236 \mathrm{MTCO}_{2} \mathrm{e}$ (Tab. 6) for processing whole of the shale gas reserves-WA.

\subsection{End use emissions}

In this study, an end use is assumed to be electricity generation. There are two possibilities: using the gas for the domestic market (including transport in Australia via pipelines and burning it for electricity generation or exporting the gas. Two scenarios have been considered. Scenario 1: domestic, Scenario 2: export to China.

\subsubsection{Liquefied natural gas processing and electricity generation}

To produce liquefied petroleum gas, the gas first has to be cooled to $-150^{\circ} \mathrm{C}$ at high pressure, and then the gas is expanded and cooled to $-160^{\circ} \mathrm{C}$ at atmospheric pressure.
At this temperature, the gas is maintained in a liquid state [22]. At the end the LNG is piped to a storage tank at the same temperature. At all these stages there occur GHG emissions. Next are the transport and the regasification. The LNG transport is mostly done in bubble shipping because the LNG has to be maintained at $-160^{\circ}$ and under pressure [23].

The final stage of end use is electricity generation. An emission factor for electricity generation for China and Australia has been used to calculate emissions from electricity generation after LNG export. First we estimate how many kilowatt hours of electricity are generated from $1 \mathrm{~m}^{3}$ of gas. A factor to estimate the quantity of $\mathrm{CO}_{2} \mathrm{e}$ released per kWh and then MWh has been used. According to ABRAXAS [24], $10.54 \mathrm{kWh}$ is generated from $1 \mathrm{~m}^{3}$ of pure methane gas. In China electricity generation with natural gas produces between 0.43 and $0.59 \mathrm{t}$ of $\mathrm{CO}_{2} \mathrm{e}$ per MWh. When the emissions from gas production processing were compared with that of electricity generation we figured out that its in the ratio of $22 \%: 78 \%$ as shown in Figure 2. It is in line with established "rules of thumb" that production emissions constitute $15-25 \%$ while end use emissions constitute $75-85 \%$ GHG emissions $[11,21]$.

\subsection{Domestic vs international emissions}

It is estimated that the domestic emissions from fracking could be $245 \mathrm{MTCO}_{2} \mathrm{e} /$ year and international emissions could be $502 \mathrm{MTCO}_{2} \mathrm{e} /$ year for a 20-year life span of gas well (Fig. 2). The domestic emissions include; well completion to the processing of the gas, while international emissions include; LNG transport regasification and electricity generation. Now, this annual figure including the end use scenario in China is equivalent to the Australian national emissions for 2014 cover $525 \mathrm{MTCO}_{2} \mathrm{e}$ [8] in 2014. 


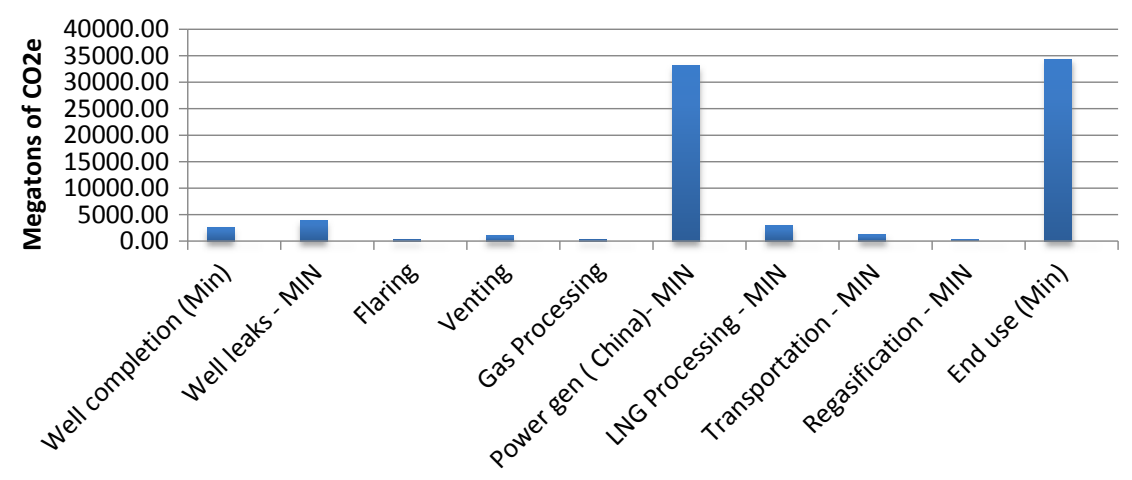

Fig. 3. Emission from each development stages in an export scenario for $280 \mathrm{TCF}$ of shale gas.

The emissions from end use (electricity generation) are the largest portion in the lifecycle of shale gas. In the case of extractive emissions, well completion, well leaks (postproduction), and LNG processing are found to be the dominant emission sources (Fig. 3).

\section{Discussion}

This paper has compared the emissions from fracking with latest Australian GHG emissions for 2014 which were $525 \mathrm{MTCO}_{2} \mathrm{e} /$ year [8]. Yet, it is not fully representative due to confidentiality of the data [8]. If all of the resource extracted is exported to China the estimated emissions from Cradle to Grave (502.3 $\mathrm{MTCO}_{2} /$ year) are equivalent to the national GHG emissions for 2014. It implies that if all of the shale gas, under the assumed conditions of this study is exploited it will challenge Australia's goal of achieving net zero emissions by 2050 via decarbonising the economy in a post-Kyoto agreement on climate change. In contrast, better regulation can help push the fracking industry towards reduced emissions. For example, in Japan, LNG imports achieving zero emissions are rewarded by qualifying the energy source to be traded in a special market reserved for renewable energies (hydropower and nuclear) or fossil fuels holding sufficient green abatements [25]. Furthermore, the lower emissions in the Piceance Basin in Colorado in the USA are largely due to a higher use of lowbleed pneumatics, enforced through stricter State regulations [26].

\section{Conclusion}

This paper concludes that onshore gas fracking without any control mechanism could not be considered as a transition fuel for climate change mitigation in Australia. Fracking emissions could be a highly significant source of GHG emissions nationally as well as globally. In this context, it will be important to invest in the development of renewable energy resources to meet national climate goals. Also, it is vital to closely examine all fracking proposals and tighten up the legislation on venting, flaring and other emissions across the production stages. It will be important to promote efficient production systems in the fracking process by learning from the experiences of the established shale gas industry, mainly the USA.

\section{References}

1. M.S. Mauter, P.J.J. Alvarez, A. Burton, D.C. Cafaro, W. Chen, K.B. Gregory, G. Jiang, Q. Li, J. Pittock, D. Reible, J. L. Schnoor, Regional variation in water-related impacts of shale gas development and implications for emerging international plays, Environ. Sci. Technol. 48, 8298 (2014)

2. EPA, Hydraulic Fracturing Background Information (2012), Available from: http://water.epa.gov/type/groundwater/ uic/class2/hydraulicfracturing/wells_hydrowhat.cfm

3. R. Howarth, R. Santoro, A. Ingraffea, Methane and the greenhouse-gas footprint of natural gas from shale formations, Clim. Change 106, 679 (2011)

4. R. Glancy, IPCC 2014, 2013 revised supplementary methods and good practice guidance arising from the Kyoto protocol, in Quantifying Fugitive Emission Factors from Unconventional Natural Gas Production Using IPCC Methodologies, Institute for Global Environmental Strategies, Japan edited by T. Hiraishi, T. Krug, K. Tanabe, N. Srivastava, J. Baasansuren, M. Fukuda, T.G. Troxler (IPCC, Switzerland, 2013), p. 45

5. T. Howard, University of Texas study underestimates national methane emissions at natural gas production sites due to instrument sensor failure, Energy Sci. Eng. 3, 443 (2015)

6. J.P. Barnett, Life Cycle Assessment (LCA) of Liquefied Natural Gas (LNG) and its environmental impact as a low carbon energy source, Bachelor of Engineering (Environmntal), University of Southern Queensland, 2010

7. P. Cook, V. Beck, D. Brereton, R. Clark, B. Fisher, S. Kentish, J. Toomey, J. Williams, Engineering Energy: Unconventional Gas Production (2013)

8. Australian Government, Australian Greenhouse Emissions Information System (2016), Available from: http://ageis. climatechange.gov.au/ (last consulted on: 2016/10/09)

9. DMP, Implications for Western Australia of hydraulic fracturing for unconventional gas (L.C.W. Australia, Western Australia, 2015)

10. D.T.B. Leather, A. Bahadori, C. Nwaoha, D.A. Wood, A review of Australia's natural gas resources and their exploitation, J. Nat. Gas Sci. Eng. 10, 68 (2013)

11. P.E. Hardisty, T.S. Clark, R.G. Hynes, Life cycle greenhouse gas emissions from electricity generation: a comparative analysis of australian energy sources, Energies 5, 872 (2012)

12. D.R. Caulton, P.B. Shepson, R.L. Santoro, J.P. Sparks, R.W. Howarth, A.R. Ingraffea, M.O.L. Cambaliza, C. Sweeney, A. Karion, K.J. Davis, B.H. Stirm, S.A. Montzka, B.R. Miller, 
Toward a better understanding and quantification of methane emissions from shale gas development, Proc. Natl. Acad. Sci. U. S. A. 111, 6237 (2014)

13. O. Schneising, J.P. Burrows, R.R. Dickerson, M. Buchwitz, M. Reuter, H. Bovensmann, Remote sensing of fugitive methane emissions from oil and gas production in North American tight geologic formations, Earth's Fut. 2, 548 (2014)

14. EPA, Hydraulic Fracturing Background Information (2012), Available from: http://water.epa.gov/type/groundwater/ uic/class2/hydraulicfracturing/wells_hydrowhat.cfm

15. M. Binnion, How the technical differences between shale gas and conventional gas projects lead to a new business model being required to be successful, Mar. Petrol. Geol. 31, 3 (2012)

16. A. Burnham, J. Han, C.E. Clark, M. Wang, J.B. Dunn, I. Palou-Rivera, Life-cycle greenhouse gas emissions of shale gas, natural gas, coal, and petroleum, Environ. Sci. Technol. 46, 619 (2012)

17. H. McJeon, J. Edmonds, N. Bauer, L. Clarke, B. Fisher, B.P. Flannery, J. Hilaire, V. Krey, G. Marangoni, R. Mi, K. Riahi, H. Rogner, M. Tavoni, Limited impact on decadal-scale climate change from increased use of natural gas, Nature 514, 482 (2014)
18. International Association of Oil and Gas, Flaring \& venting in the oil \& gas exploration $\&$ production industry (2000)

19. Department of Mines and Energy, Submission to Northern Territory Government - Public Inquiry into Hydraulic Fracturing Contact: Energy, Energy Directorate (2015)

20. Western Australia Government, Guide to the Regulatory Framework for Shale and Tight Gas in Western Australia (2015)

21. T. Skone, Life Cycle Greenhouse Gas Inventory of Natural Gas Extraction, Delivery and Electricity Production (2011)

22. H. Hondo, Life cycle GHG emission analysis of power generation systems: Japanese case, Energy 30, 2042 (2005)

23. S. Rathnayaka, F. Khan, P. Amyotte, Accident modeling approach for safety assessment in an LNG processing facility, J. Loss Prev. Process Ind. 25, 414 (2012)

24. ABRAXAS, Energy conversion (2016), Available from: http://www.abraxasenergy.com/energy-resources/toolbox/ conversion-calculators/energy/

25. T. Okamura, M. Furukawa, H. Ishitani, Future forecast for life-cycle greenhouse gas emissions of LNG and city gas 13A, Appl. Energy 84, 1136 (2007)

26. D. Rahm, Regulating hydraulic fracturing in shale gas plays: the case of Texas, Energy Policy 39, 2974 (2011)

Cite this article as: Sangita Bista, Philip Jennings, Martin Anda, Cradle to grave GHG emissions analysis of shale gas hydraulic fracking in Western Australia, Renew. Energy Environ. Sustain. 2, 45 (2017) 